\title{
KAJIAN POTENSI MANUSIA SESUAI DENGAN HAKIKATNYA DALAM PENDIDIKAN HOLISTIK
}

\author{
Zalik Nuryana \\ Universitas Ahmad Dahlan Yogyakarta. \\ Email: zalik.nuryana@pai.uad.ac.id
}

\begin{abstract}
ABSTRAK
Manusia adalah makhluk sepurna unik yang memiliki banyak hal yang menarik untuk dikaji dan dibahas. Hakikat manusia tidak akan ditangkap secara utuh karena banyaknya dimensi yang dikandungnya. Setiap seseorang selesai memahami dari satu dimensi tentang manusia, maka muncul dimensi lain yang belum dibahas. Latar belakang tulisan ini adalah kurangnya kesadaran tentang hakikat dasar manusia yang menjadikan arah pendidikan berbelok jalannya. Pendidikan yang merupakan jalan untuk mengembangkan potensi yang dimiliki manusia akhirnya tidak sampai tujuan. Orientasi pengetahuan dalam pendidikan menjadi salah satu indikasinya. Penetian ini merupakan penelitian kualitatif dengan pendekatan deskriptif analitis untuk menguraikan dan menganalisis pendidikan holistik yang dikaji sesuai hakikat manusia dari sisi filosofis. Objek dari kajian ini adalah manusia, yang berperan menjadi objek dan subjek pendidikan. Hasil dari kajian ini adalah: 1). Pendidikan merupakan perwujudan dari cita-cita hidup manusia untuk mengembangkan dan mentransformasikan nilai-nilai ilahiah dan insaniah, dan membekali peserta didik dengan kemampuan produktif agar dapat berfungsi dan berkembang sesuai dengan zaman. 2). Manusia itu terdiri dari komponen jasmani-ruhani-akal, konsepsi itu menghendaki proses pembinaan yang nyata, sehingga pendidikan harus dibangun di atas konsep kesatuan jasmani, ruhani, dan akal sehingga menghasilkan seorang muslim yang cerdas intelektual dan terpuji moralnya. 3). Manusia mempunyai respon berbeda antar satu dengan yang lain, tugas pendidikan adalah memahami perbedaan ini dan mengembangkan sesuai dengan responnya. Sehingga tidak ada pemaksaan kehendak dalam proses pendidikan. Kajian pendidikan melalui pendekatan holistik diharapkan mampu melaksanakan amanah pengembangan potensi manusia dengan baik. Adanya kesadaran kolektif dalam memahami manusia sesuai dengan hakikatnya, diharapkan menjadi pelita pendidikan yang esensinya mulai redup.
\end{abstract}

\section{Kata kunci : Pendidikan, Holistik, Islam, Manusia.}

\section{Pendahuluan}

Membicarakan manusia tentu tidak akan pernah habis. Manusia merupakan makhluk yang sangat menarik. Oleh karena itu, manusia dan berbagai hal dalam dirinya sering menjadi perbincangan diberbagai kalangan. Jika sesorang merasa tuntas membicarakanya berarti sama dengan memperkecil makna dan kandungan kapabilitas manusia itu sendiri (Maragustam, 2010:72). Hakikat manusia tidak akan pernah ditangkap secara utuh karena banyaknya dimensi yang dikandungnya. Maka setiap kali seseorang selesai memahami dari satu dimensi tentang manusia, maka muncul dimensi lain yang belum dibahas. Banyaknya permasalahan pendidikan yang lahir belakangan ini menjadi salah satu indikasi bahwa dimensi pendidikan yang berdasar atas hakikat manusia kurang di pahami. Penekanan pada ranah kognitif belakangan lebih ditonjolkan, kepandaikan akal lebih menjadi tujuan pendidikan, sehingga pendidikan tercabut dari ruhnya sendiri.

Manusia dan pendidikan bagai dua sisi mata uang yang tidak bisa dipisahkan. Manusia dimana pun ia berada, dipastikan akan butuh dengan pendidikan, hal ini disebabkan karena fungsi utama dari pendidikan adalah mengembangkan seluruh potensi manusia yang ada ke arah lebih baik atau ke arah yang menjadi cita-cita manusia (Haidar Putra, 2004:3). Berbicara manusia 
dan pendidikan adalah hal yang sangat menarik. Manusia sebagai objek dan sekaligus berperan sebagai subjek pendidikan itu sendiri.

Pendidikan Islam merupakan suatu proses yang berkaitan dengan kegiatan mempersiapkan dan mengembangkan seluruh potensi manusia baik yang bersifat materi maupun immateri, serta membentuk pandanganya terhadap dirinya sendiri, alam, kehidupan, dan masyarakatnya sesuai dengan nilai-nilai Islam. Sehingga sebelum melakukan praktik pendidikan harus memahami nilai-nilai dasar yang harus dipegang. Pemahaman tentang penentuan sikap dan tanggapan tentang manusia sangat penting dan vital, tanpa sikap dan tanggapan yang jelas, pendidikan akan meraba-raba (al-Syaibani dan Omar Muhammad, 1979:10) Hal itu dimaksudkan agar dalam proses pendidikan tidak kehilangan orientasi atau tercabut dari akar spirit Islamnya. Sehingga dalam makalah ini akan kita bahas mengenai aliran filsafat tentang manusia, hakikat manusia dalam pandangan Islam.

\section{Metode Penelitian}

Penetian ini merupakan penelitian kualitatif dengan pendekatan deskriptif analitis untuk menguraikan dan menganalisis pendidikan holistik yang dikaji menurut hakikat dasar manusia dari sisi filosofis. Meramu hakikat dasar manusia yang disampaikan dalam alQur'an, aliran-aliran pembentuk manusia dan realitas pendidikan yang dilaksanakan di Indonesia. Mendiskripsikan hakikat dasar manusia kemudian menganalisis implikasi dalam pendidikan, dalam rangka kajian potensi manusia secara holistik.

\section{Pembahasan}

\section{Aliran filsafat tentang manusia}

Setidaknya terdapat empat aliran pemikiran yang berkaitan tentang masalah rohani dan jasmani (sudut pandang unsur pembentuk manusia) yaitu: Aliran serba zat, aliran serba ruh, aliran dualisme, dan aliran Eksistensialisme (Zuhaerini, 1995:71).

\section{Serba zat.}

Aliran serba zat ini mengatakan yang sungguh-sunguh ada itu adalah zat atau materi, alam ini adalah zat atau materi dan manusia adalah unsur dari alam, maka dari itu manusia adalah zat atau materi. Manusia ialah apa yang nampak sebagai wujudnya, terdiri atas zat (darah, daging, tulang).

Aliran ini lebih berpemahaman bahwa esensi manusia adalah lebih kepada zat atau materinya. Manusia sebagai makhluk materi, maka pertumbuhanya berproses dari materi juga. Sel telur dari sang ibu bergabung dengan sperma dari ayah. Tumbuh menjadi janin, yang akhirnya ke dunia sebagai manusia. Manusia bergerak menggunakan organ, makan dengan tangan, berjalan dengan kaki, dll. Semua serba zat atau meteri. Berdasar aliran ini, maka dalam pendidikan manusia harus melalui proses mengalami atau pratek (psikomotor).

\section{Serba Ruh.}

Aliran ini berpendapat bahwa segala hakikat sesuatu yang ada di dunia ini adalah ruh, juga hakekat manusia adalah ruh. Adapun zat adalah sebagai manifestasi dari ruh di atas dunia ini. Ruh adalah sesuatu yang tidak menempati ruang, sehingga tak dapat disentuh atau dilihat oleh panca indra. Ruh disini bisa diartikan juga sebagai jiwa, mental, juga rasio/akal. Karena itu, jasmani atau tubuh (materi, zat) merupakan alat jiwa untuk melaksanakan tujuan, keinginan dan dorongan jiwa (rohani, spirit, rasio) manusia. Dasar pemikiran ini adalah bahwa ruh itu lebih berharga, lebih tinggi nilainya dari pada materi.

Aliran ini beranggapan bahwa yang menggerakkan tubuh itu adalah ruh atau jiwa. Tanpa ruh atau jiwa maka jasmani, raga atau fisik manusia akan mati, sia-sia dan tidak berdaya sama sekali. Dalam pendidikan, maka tidak hanya aspek pengalaman saja yang diutamakan, faktor dalam seperti potensi bawaan (intelegensi, rasio, kemauan dan perasaan) memerlukan perhatian juga.

\section{Dualisme.}

Aliran ini mencoba mengawinkan kedua aliran tersebut di atas. Aliran ini menganggap bahwa manusia itu pada hakekatnya terdiri dari dua substansi, yaitu 
jasmani dan rohani, badan dan ruh. Kedua substansi ini masing-masing merupakan unsur asal yang adanya tidak tergantung satu sama lain. Jadi badan tidak berasal dari ruh, juga sebaliknya ruh tidak berasal dari badan (1995:73). Aliran ini melihat realita semesta sebagai sintesa kedua kategori animate dan inanimate, makhluk hidup dan benda mati. Demikian pula manusia merupakan kesatuan rohani dan jasmani, jiwa dan raga.

Misalnya ada persoalan: dimana letak mind (jiwa, rasio) dalam pribadi manusia. Mungkin jawaban umum akan menyatakan bahwa rasio itu terletak pada otak. Akan tetapi akan timbul problem, bagaimana mungkin suatu immaterial entity (sesuatu yang non-meterial) yang tiada membutuhkan ruang, dapat ditempatkan pada suatu materi (tubuh jasmani) yang berada pada ruang wadah tertentu.

Aliran ini meyakini bahwa sesungguhnya manusia tidak dapat dipisahkan antara zat/raga dan ruh/jiwa. Karena pada hakekatnya keduanya tidak dapat dipisahkan. Masing-masing memiliki peranan yang sama-sama sangat vital. Jiwa tanpa ruh ia akan mati, ruh tanpa jiwa ia tidak dapat berbuat apa-apa. Dalam pendidikan pun, harus memaksimalkan kedua unsur ini, tidak hanya salah satu saja karena keduanya sangat penting.

\section{Eksistensialisme.}

Pembicaraan mengenai hakikat manusia ternyata terus menerus berjalan dan tak kunjung berakhir. Ahli-ahli filsafat modern dengan tekun berfikir lebih lanjut mengenai hakikat manusia yang merupakan eksistensi atau wujud sesungguhnya dari manusia itu. Jadi inti hakikat manusia adalah apa yang menguasai manusia secara menyeluruh. Disini manusia dipandang tidak dari serba zat, serba ruh atau dualisme dari kedua aliran itu, tetapi memandangnya dari segi eksistensi manusia itu sendiri di dunia, yaitu cara beradanya manusia itu sendiri di dunia ini.

\section{Hakikat manusia dalam pandangan Islam}

Manusia bukanlah problem yang akan habis dipecahkan, melainkan misteri yang tidak mungkin disebutkan sifat dan ciricirinya secara tuntas dan karena itu harus dipahami dan dihayati. Mengkaji manusia dari satu dimensi akan membawa stagnasi pemikiran pemikiran tentang karakteristik manusia, sekaligus menjadikanya sebagai objek yang statis (2010:73). Manusia adalah makhluk yang terdiri dari berbagai komponen, yaitu jasad, ruh, dan akal, yang menjadi potensi manusia sekaligus pembeda antara manusia dengan makhluk lain. Hal ini dijelaskan dalam al-Qur'an surat al-Isra':70

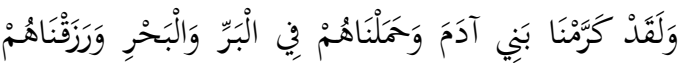

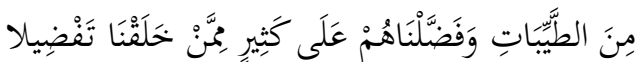

Artinya :

Dan Sesungguhnya telah Kami muliakan anak-anak Adam, Kami angkut mereka di daratan dan di lautan], Kami beri mereka rezki dari yang baik-baik dan Kami lebihkan mereka dengan kelebihan yang sempurna atas kebanyakan makhluk yang telah Kami ciptakan.

\section{Proses Penciptaan Manusia}

Tuhan menciptakan manusia terdiri dari unsur ruh dan jasad. Proses penciptaanya rumit dan penuh misteri sebanding dengan jadi dirinya yang unik, misteri, dan tak terduga. Ruh dan jasad, adalah dua unsur yang tidak bisa dipisahkan antara satu dengan lainya yang merupakan satu kesatuan dan saling menyempurnakan dalam pembentukan yang namanya manusia (2010:75).

Penyebutan asal penciptaan manusia dalam Al-Quran, sebagai berikut:

1. Manusia diciptakan dari tanah liat kering dari lumpur hitam yang diberi bentuk. (QS. al-Hijr:28)

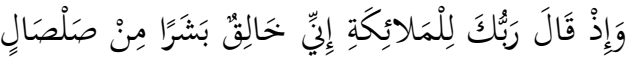

$$
\begin{aligned}
& \text { مِنْ حَمَاِِ مَسْنُوِن }
\end{aligned}
$$

Artinya:

Dan (ingatlah), ketika Tuhanmu berfirman kepada Para Malaikat: "Sesungguhnya aku akan menciptakan seorang manusia dari tanah liat kering (yang berasal) dari lumpur hitam yang diberi bentuk." 
2. Manusia diciptakan dari saripati tanah, air mani yang disimpan, segumpal daging, tulang belulang, tulang kemudian dibungkus daging, dan akhirnya menjadi makhluk yang sempurna. (QS.al-Mu'minun :12-14)

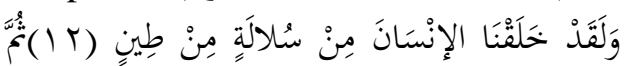

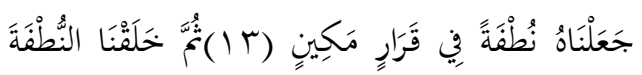

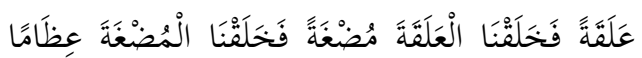

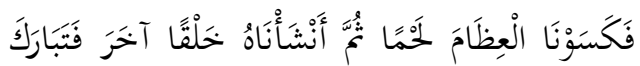

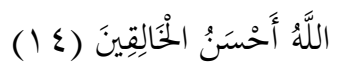

Artinya :

Dan Sesungguhnya Kami telah menciptakan manusia dari suatu saripati (berasal) dari tanah.(12)kemudian Kami jadikan saripati itu air mani (yang disimpan) dalam tempat yang kokoh (rahim).(13)kemudian air mani itu Kami jadikan segumpal darah, lalu segumpal darah itu Kami jadikan segumpal daging, dan segumpal daging itu Kami jadikan tulang belulang, lalu tulang belulang itu Kami bungkus dengan daging. kemudian Kami jadikan Dia makhluk yang (berbentuk) lain. Maka Maha sucilah Allah, Pencipta yang paling baik.(14).

3. Pengambilan kesaksian manusia sebelum ditiupkan ruh. (QS.alA'raf:172)

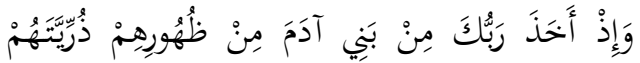

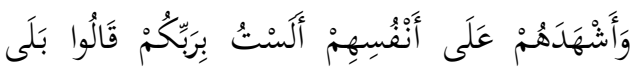

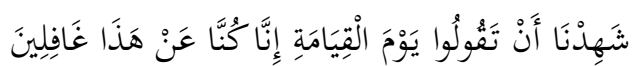
Artinya:

Dan (ingatlah), ketika Tuhanmu mengeluarkan keturunan anak-anak Adam dari sulbi mereka dan Allah mengambil kesaksian terhadap jiwa mereka (seraya berfirman): "Bukankah aku ini Tuhanmu?" mereka menjawab: "Betul (Engkau Tuban kami), Kami menjadi saksi". (kami lakukan yang demikian itu) agar di hari kiamat kamu tidak mengatakan: "Sesungguhnya Kami (Bani Adam) adalah orang-orang yang lengah terhadap ini (keesaan Tuhan).
4. Ditiupkan ruh kepada manusia. (QS.alHijr:29)

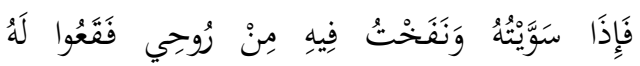
سَابِجِينَ

Artinya:

Maka apabila aku telah menyempurnakan kejadiannya, dan telah meniup kan kedalamnya ruh (ciptaan)$\mathrm{Ku}$, Maka tunduklah kamu kepadanya dengan bersujud

\section{Perangkat jati diri dan potensi manusia}

Manusia diciptakan tuhan terdiri dari unsur roh dan tubuh dengan cara yang rumit dan penuh misteri, dan tak terduga.perangkat pembentukan zat insaniyah dan menunjuk pada potensinya. Al-Qur'an menggunakan beberapa terma diantaranya; insan, basyar, al-jism, 'aql, qalb, nafs, dan fitrah. Semua terma tersebut membentuk manusia dan satu sama lain tidak dapat dipisahkan.

\section{Terma Insan}

Manusia jika merujuk kepada kata insan, nasiya mengacu kepada manusia dari aspek mental-spiritualnya. Kata insan dari asal kata nasiya yang artinya lupa. Sedangkan insan dilihat dari asalnya al-uns dapat berarti jinak. Insan dari asal kata nasiya yang berarti lupa atau salah. Manusia memiliki sifat salah dan lupa. Manusia lupa terhadap suatu hal disebabkan ia kehilangan kesadaran terhadap sesuatu.

Insan dilihat dari asalnya al-uns dapat berarti jinak. Manusia pada dasarnya adalah makhluk yang jinak, yang berbudaya, dan dapat mendidik dan dididik serta dapat beradaptasi dengan lingkungan, baik alam maupun sosial.

\section{Terma Basyar}

Manusia jika merujuk kepada kata albasyar mengacu manusia dari aspek lahiriahnya. Kata basyar dipakai untuk menyebut semua makhluk, baik laki-laki maupun perempuan, baik secara individu maupun kolektif. Dengan demikian jika manusia mengacu pada aspek lahiriah yang dapat tumbuh secara alami sesuai dengan makanan dan minuman yang dikonsumsinya. 


\section{Terma Jism}

Manusia jika merujuk jism (tubuh) menunjukkan bahwa jasad manusia termasuk tabiat manusia dan harus diperhatikan pula, bahwa kekuatan fisik dapat membantu seseorang dalam menjalankan tugasnya. Namun sebaliknya anggota tubuh juga dapat menjerumuskan seseorang ke dalam maksiat. Keperkasaan tubuh dan kesempurnaan kekuatanya merupakan modal untuk sehat pikiran. Dalam perumpamaan dikatakan bahwa di dalam akal yang sehat terdapat tubuh

\section{Terma al-'Aql}

Kata 'aql dengan kata jadiannya dimuat dalam Al-Qur'an dalam 49 kali. Sedangkan kata al-albab dalam 16 kali. AlQur'an tidak menjelaskan secara eksplisit mengenai arti yang menggunakan akar kata 'aql dan albab, namun dari konteks ayatayat dapat dipahami maknanya sebagai berikut:

1. Akal sebagai alat untuk memahami dan menggambarkan sesuatu agar seseorang mencapai hakikat yang menuntun agar beriman kepada-Nya.

2. Penggambaran dan perumpamaan yang diberikan Al-Qur'an untuk menuntun seseorang memahami dan mengantarkannya kepada keimanan.

3. Akal berfungsi sebagai dorongan moral.

4. Akal sebagai daya untuk mengambil pelajaran dan kesimpulan serta hikmah dari sesuatu peristiwa.

\section{Terma al-Qalb}

Kata al-qalb dan al-qulub dan segala kata jadiannya tidak kurang dari 170 ayat yang tersebar di beberapa surah A-Qur'an. Menurut Imam al-Ghazali bahwa kalbu itu mempunyai dua pengertian. Pertama, ia segumpal daging yang berbentuk bulat memanjang yang terletak di pinggir dada sebelah kiri yang mempunyai tugas khusus di dalamnya ada rongga yang mengandung darah hitam sebagai sumber roh. Kedua, ia berupa sesuatu yang halus bersifat ketuhanan dan kerohanian yang ada hubunganya dengan jasmani.

Qalb adalah salah satu gelajala dari perangkat hakikat manusia yang asasi karena iman bersemayam di kalbu yang dengannya dapat menangkap segala rasa. Dengan demikian kalbu merupakan tempat bersemayam iman, pusat kesadaran normal, dan alat memperoleh ilmu.

\section{Terma Nafs}

Kata nafs bermacam maknanya. Menurut Quraish Shihab, terkadang diartikan sebagai totalitas manusia. Kata nafs yang berkaitan dengan manusia menunjuk kepada sisi dalam manusia yang berpotensi baik dan buruk.

\section{Terma Fitrah}

Kata fitrah dan segala bentuk kata jadiannya tertera pada 19 ayat 17 surat. Dari segi bahasa, kata fitrah diambil dari kata al-fatr yang berarti cara penciptaan, sifat pembawaan lahir, watak manusia, agama dan sunnah. Dapat dirangkum bahwa fitrah adalah sistem aturan atau potensi yang diciptkan kepada setiap makhluk sejak keberadaannya baik ia makhluk manusia atau lainnya. Seperti bawaan dasar manusia cenderung kepada agama tauhid, kebenaran, keadilan, wanita, harta benda, anak, dan lain-lain. (2010:7394).

\section{Kedudukan manusia di dunia}

Penentuan kedudukan manusia diciptakan ini, tentu bukan berasal dari manusia, tapi sungguh-sungguh berasal dari penciptanya. Karena manusia tidak pernah menentukan dan berkompromi kapan ia lahir, dimana dia lahir, dari rahim siapa ia lahir dan fungsi apa yang harus dijalankan (2010:95). Menurut Zuhairini, setidaknya ada tujuh kedudukan manusia di dunia (1995:85-90):

1. Sebagai pemanfaat dan penjaga kelestarian alam.(QS.al-Jum'at:10 dan al-Baqarah:60)

2. Sebagai peneliti alam dan dirinya untuk mencari Tuhan.(QS.al-Baqarah:164)

3. Sebagai khalifah di muka bumi.(QS.alAn'am:165)

4. Sebagai makhluk yang paling tinggi dan paling mulia.(QS.at-Tin:4 dan alIsra':70)

5. Sebagai hamba Allah.(QS.ali-Imran:83 dan adz-Dzariat:56) 
6. Sebagai makhluk yang bertanggung jawab.(QS.at-Takatsur:8 dan an-Nur:2425

7. Sebagai makhluk yang dapat dididik dan mendidik.(QS.al-Baqarah:31 dan alAlaq:1-5)

\section{Imlplikasi hakikat manusia dalam pendidikan}

Manusia merupakan makhluk sempurnya yang dibekali akal untuk dapat berfikir, pendidikan merupakan perwujudan dari cita-cita hidup manusia untuk dapat menginternalisasikan, mentransformasikan, dan mengembangkan nilai ilahiyah dan insaniyah dengan membekali kemampuan untuk berfungsi sesuai dengan perkembangan. Pendidikan merupakan manifestasi dari cita-cita hidup manusia untuk melestarikan, mengalihkan, menanamkan, serta mentransformasikan nilai-nilai ilahiah dan insaniah serta membekali peserta didik dengan kempuan yang produktif agar dapat berfungsi dan berkembang seirama dengan perkembangan zaman.

Manusia terdiri dari dua unsur komponen materi dan immateri (jasmaniruhani), komponen tersebut menghendaki proses dan pembinaan yang mengarah kepada kematangan jasmani-ruhani. Hal ini memberikan sinyal bahwa pendidikan harus dibangun dengan fondasi kesatuan (integrasi) antara pendidikan jasmani-ruhani (qalbiyah-aqliyah), sehingga menghasilkan manusia yang cerdas secara intelektual dan terpuji secara moral (moral and intellectual Integrity). Pendidikan saat ini yang lebih mengarah pada orientasi kecerdasan akal, harus segera berbenah. Pendidik mempunyai kewajiban dalam mengembangkan semua aspek manusia, karena pendidikan seharusnya mengembangkan hakikat manusia, sehingga tujuan pendidikan sejalan dengan hakikat manusia.

Manusia punya potensi yang berbeda. Respon terhadap sesuatu hal tentu berbeda antara satu dengan yang lain. Pendidikan harus mampu memahami perbedaan ini, pendidikan harus merespon secara menyeluruh dan menyadari bahwa pendidikan bukan memaksakan dan menyamakan kemampuan anak, tetapi pendidikan mampu mengembangkan potensi dasar manusia (ketuhanan) dalam proses pendidikan. Pengembangan potensi, pengembangan aspek dasar, dan juga menumbuhkan sifat dasar manusia tidak akan bisa dilaksanakan tanpa sebuah proses, proses inilah yang kita kenal dengan pendidikan. Sehingga apabila cita-cita pendidikan adalah untuk mengembangkan seluruh potensi manusia, maka praktik pendidikan harus juga memperhatikan hakikat-hakikat dasar manusia. Itulah konsepsi pendidikan holistik (menyeluruh).

\section{Kesimpulan}

Dari pembahasan tentang hakikat manusia dan alam di atas, maka dapat disimpulkan bahwa Ada empat aliran pemikiran yang berkaitan tentang masalah rohani dan jasmani dari sudut pandang unsur pembentuk manusia, yaitu: Aliran serba zat, aliran serba ruh, aliran dualisme, dan aliran aksistensialisme. Aliran-aliran inilah yang harus kita fahami, sehingga dalam melaksanakan proses pendidikan sikap dan implementasi pendidikan kita tepat. Pendidikan menggunakan melalui pendekatan holistik diharapkan mampu melaksanakan amanah pengembangan potensi manusia dengan baik. Adanya kesadaran dari pendidik (guru/dosen) dalam memahami manusia dan pendidikan diharapkan mampu menjadi pelita pendidikan yang esensinya semakin redup. Perkembangan pendidikan di Indonesia yang berkembang secara konseptual dan didukung perkembangan zaman, ternyata belum mampu menjawab beberapa persoalan kehidupan.

Tuhan menciptakan manusia terdiri dari unsur ruh dan jasad yang keduanya tidak bisa dipisahkan antara satu dengan lainya dan merupakan satu kesatuan untuk saling menyempurnakan dalam pembentukan yang namanya manusia. Kedua unsur tersebut harus juga di kembangkan, mengembangkan ruh dan jasad tidak bisa dilaksanakan tanpa adanya campur tangan pendidikan. Sehingga pendidikan mempunyai kewajiban untuk mengembangkan unsur ruh dan jasad. Al- 
Qur'an menggunakan beberapa terma untuk menjelaskan manusia, diantaranya; insan, basyar, al-jism, 'aql, qalb, nafs, dan fitrah. Terma inilah yang juga menjadi indikasi beberapa sifat manusia, pendidikan berfungsi untuk mengembangkan dan mengarahkan terma-terma yang dijelaskan dalam al-Qur'an. Pendidikan holistik diharapkan mampu menjawab tantangan zaman yang semakin berkembang, sehingga kesadaran akan pendidikan akan mampu tumbuh secara holistik. Pemahaman pendidikan yang holistik akan mempentuk pola dan pelaksanaan pendidikan yang holistik pula. Dengan demikian pendidikan di Indonesia akan mampu membawa kebaikan dan kebangkitan Indonesia menuju negara yang berkemajuan.

\section{Daftar pustaka}

Baharuddin dan Makin. M. 2006. Pendidikan Humanistik. ar-Ruzz Media, Yogyakarta.

Daulay dan Putra. H. 2004. Pendidikan Islam dalam Sistem Pendidikan Nasional di Indonesia. Prenada Media. Jakarta.

Departemen Agama RI. 2005. AlQur'an dan Terjemah. Syaamil Cipta Media. Jakarta.

Jalaluddin. 2003. Teologi Pendidikan. Edisi 3. Grafindo Persada. Jakarta.
Kartanegara.M. 2007. Nalar Religius, Memahami Hakikat Tuhan, Alam, dan Manusia. Erlangga. Jakarta.

Langgulung, H. 1995. Pendidikan dan Peradaban Islam. Pustaka Al-Husna. Jakarta.

Madjid. N. 1992. Islam Doktrin dan Peradaban. Yayasan Wakaf Paramadina. Jakarta.

Muzayyin. A. 1991. Ilmu Pendidikan Islam; Suatu Tinjauan Teoritis dan Praktis Berdasarkan Pendekatan Interdisipliner. Bumi Aksara. Jakarta.

$$
\text { 2009. Filsafat Pendidikan }
$$

Islam. Edisi 4. Bumi Aksara. Jakarta.

Rasyidin, A. 2008. Falsafah Pendidikan Islam, Membangun Kerangka Ontologi, Epistimologi, dan Axiologi Praktik Pendidikan. Citapustaka Media Perintis. Bandung.

Rosyadi. K. 2004. Pendidikan Profetik. Pustaka Pelajar. Yogyakarta.

Siregar. M. 2010. Filsafat Pendidikan Islam. Sunan Kalijaga Pers. Yogyakarta.

Syaibani dan Muhammad,O.T. 1979. Falsafah Pendidikan Islam. Bulan Bintang. Jakarta.

Zahairini. 1995. Filsafat Pendidikan Islam. Bumi Aksara. Jakarta. 